\title{
Aktuálně ke stavu znalecké činnosti v ČR na začátku roku 2022
}

\section{Currently on the State of Expert Activity in the Czech Republic at the Beginning of 2022}

Albert Bradáč

emeritní profesor, Vysoké učeni technické v Brně, Ústav soudního inženýrství, Brno

\section{Abstrakt}

V př́spěvku je shrnuta korespondence autora s ministrem spravedlnosti JUDr. Pavlem Blažkem ze začátku roku 2022.

Klíčová slova: Zákon o znalcích, znalec, znalecká kancelář, znalecký ústav, odměna znalce, náklady znalecké činnosti.

\section{Abstract}

The article summarizes the author's correspondence with the Minister of Justice JUDr. Pavel Blažek from the beginning of 2022.

Keywords: Act on Experts, expert, expert office, expert institute, expert's fee, costs of expert activity.

Příspěvek navazuje na článek téhož autora z čísla 3/2021 „Příspěvek k analýze stavu znalecké činnosti v ČR v roce 2021“. Po jmenování nové vlády uvedl staronový ministr, pan JUDr. Pavel Blažek, že k jeho prioritám patří mj. řešení problematiky kritického stavu v oblasti znalecké činnosti. Autor k tomu panu ministrovi zaslal uvedený článek s průvodním dopisem, který zde citujeme, spolu s odpovědí pana ministra; věřme, že svému slibu dostojí.

Vše se odehrálo po uzávěrce čísla 4/2021 časopisu, vsunuto bylo dodatečně; níže ještě aktuální graf počtu znalců, kdy od 1 . do 17 . ledna 2022 klesl jejich počet o dalších 50 na číslo 6461.

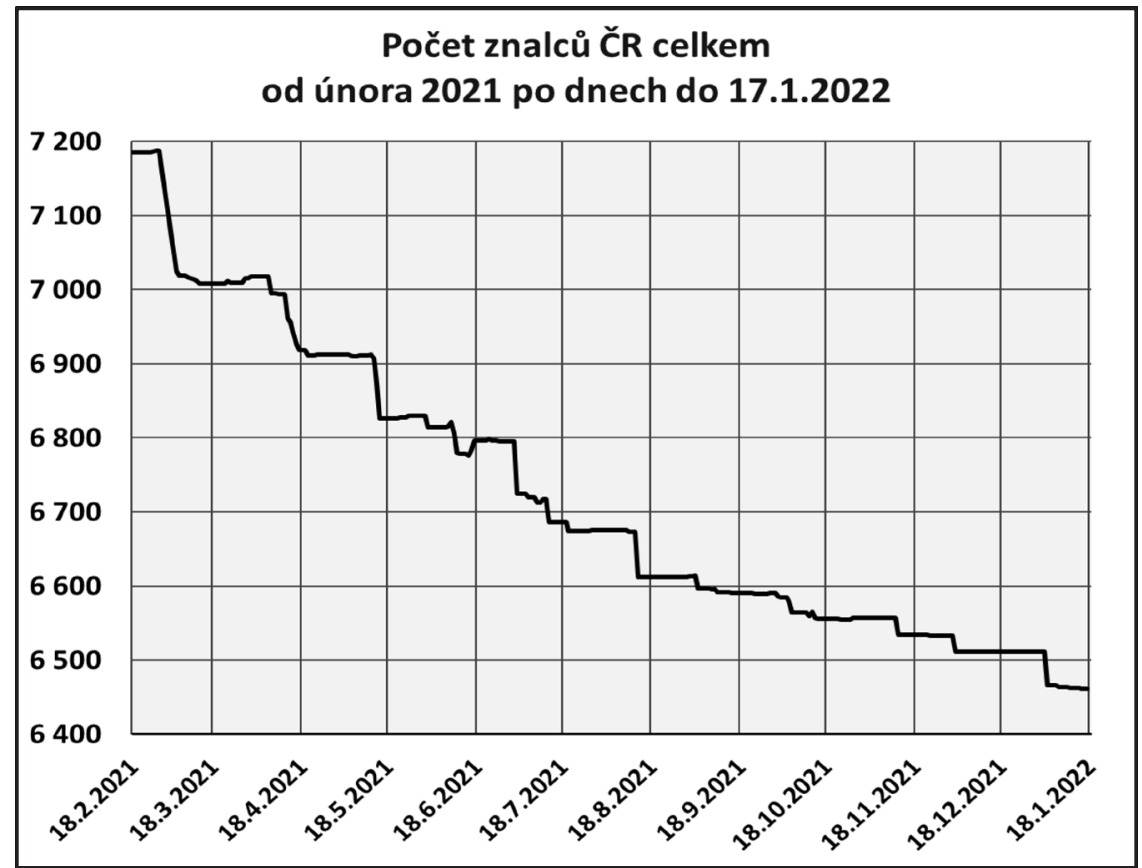

Obr. 1 Počet znalců ČR celkem - jaro a léto 2021 po dnech do 17.1.2022.

Fig. 1 Total number of experts in the Czech Republic - spring and summer 2021 after days until 17.1.2022. 


\section{Prof. Ing. Albert Bradáč, DrSc.}

emeritní profesor oboru Soudní inženýrství VUT v Brně

Brno

albert@bradac.cz

ID DS 6kcjj48

\section{Vážený pan}

\section{JUDr. Pavel Blažek}

ministr spravedlnosti

Praha

ID DS kq4aawz

V Brně dne 22. 12. 2021

Věc: Analýza stavu znalecké činnosti 2021

Vážený pane ministře,

dovolte, abych Vám upřímně blahopřál ke jmenování do funkce ministra spravedlnosti; věrím, že Vaše působení ve funkci bude podstatně př́nosnější než u Vašich předchůdců nejen pro orgány justice, ale i pro její spolupracovníky, jimiž jsou ve speciálních otázkách znalci. Vaše prohlášení po jmenování vlády k dané problematice mne inspirovala k napsání tohoto dopisu.

Dovolte mi, abych se nejprve krátce představil. Je mi 81 let, dlouhá léta jsem byl znalcem v oborech stavebnictví, ekonomika - ceny a odhady nemovitostí, doprava - technická analýza silničních nehod. Jsem autorem základních učebnic a znaleckých standardů zejména k problematice soudního inženýrství obecně, znalecké analýzy silničních nehod, resp. oceňování nemovitých věcí. Byl jsem dlouhá léta ředitelem Ústavu soudního inženýrství VUT v Brně, předsedou prezídia Asociace znalců a odhadců ČR, z.s., šéfredaktorem časopisu Soudní inženýrství. Vychovali jsme na ústavu za dobu mého působení tisíce znalců.

Celou dobu i nyní v důchodu sleduji stav znalecké činnosti v ČR a jsem bohužel čím dál více zklamán z dosavadního nadřazeného postoje resortu spravedlnosti ke znalcům a znaleckým ústavům. Již před mnoha lety jsem to nazval nevolnictvím, bohužel vývoj mi stále dává za pravdu. Podrobný rozbor se zdůvodněním si dovoluji zaslat v příloze; jedná se o můj příspěvek do aktuálního čísla $3 / 2021$ časopisu Soudní inženýrství; grafy s aktuálním stavem přikládám níže.

\section{S pozdravem}

prof. Ing. Albert Bradáč, DrSc., v.r.

Př́iloha: BRADÁČ, A. Příspěvek k analýze stavu znalecké činnosti v ČR v roce 2021. Soudní inženýrství, 2021, 32(3), 47-52. DOI: http://dx.doi.org/10.13164/SI.2021.3.47. ISSN 1211-443X.

\section{Správná citace:}

BRADÁČ, A. Aktuálně ke stavu znalecké činnosti v ČR na začátku roku 2022. Soudní inženýrství, 2021, 32(4), 26-28.

DOI: http://dx.doi.org/10.13164/SI.2021.4.26. ISSN 1211-443X. 


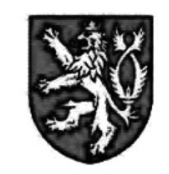

JUDr. Pavel Blažek, Ph.D.

MINISTR SPRAVEDLNOSTI ČR

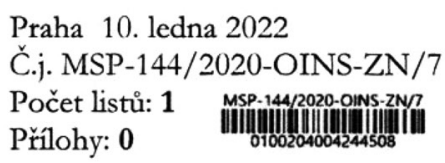

Vážený pane profesore,

tímto reaguji na Váš dopis ze dne 22. prosince 2021 týkajicí se problematiky soudních znalců, $\mathrm{v}$ němž poukazujete na vybrané problémy trápící danou oblast.

V prvé řadě bych Vám rád poděkoval za Váš dlouhodobý zájem o osud znalectví a snahu o jeho kontinuální rozvoj. Pokud jde o Vámi zdưrazňovanou otázku odměňování znalců, dovoluji si Vás ujistit, že daná problematika bude $v$ následujících měsících a letech patrit mezi priority resortu spravedlnosti a že zdejši ministerstvo podnikne aktivní kroky k vylepšení situace. Vámi provedený výzkum bude pritom využít jako podklad pro koncepční a metodickou činnost ministerstva.

S pozdravem

Vážený pan

prof. Ing. Albert Bradáč, DrSc.

DS ID: $6 \mathrm{kcjj} 48$

JUDr. Pavel Blažek, Ph.D.

Ministerstvo spravedlnosti ČR

Elektronicky podepsáno: 10.01.2022 15:21:36

Ministerstvo spravedlnosti České republiky, Vyšehradská 16, 12810 Praha 2, tel. +420 221997 111, www.justice.c\% 